\title{
Controlling threshold in soil salinity when planting spring wheat and sequential cropping silage corn in Northern Xinjiang using drip irrigation
}

\author{
Zhenhua Wang ${ }^{1,2^{*}}$, Bo Zhou ${ }^{3,4^{*}}$, Lei Pei ${ }^{1}$, Jinzhu Zhang ${ }^{1}$, Xinlin He ${ }^{1}$, Henry Lin ${ }^{2}$ \\ (1. College of Water and Architectural Engineering, Shihezi University, Shihezi 832000, Xinjiang, China; \\ 2. Department of Ecosystem Science and Management, Pennsylvania State University, University Park, PA 16802, USA; \\ 3. College of Water Resources and Civil Engineering, China Agricultural University, Beijing 100083, China; \\ 4. College of Agricultural and Life Sciences, University of Wisconsin-Madison, Madison, WI 53706, USA)
}

\begin{abstract}
Xinjiang Region of China is one of the most typical and representative arid areas worldwide, along with severe soil salinization issue. Planting spring wheat and sequential cropping silage corn in Northern Xinjiang using drip irrigation has become an effective way to relieve soil salinity stress, which improves the simple agricultural structure in the past and ensures food security in this area. However, neither the effects of different soil salinities on the growth and yield of spring wheat and silage corn, nor their desalination effect correspondingly was clear until now. Therefore, a pot experiment was conducted at Shihezi, Xinjiang from March to June 2015. The study aimed to establish the quantitative correlations between the parameters mentioned above and came up with the appropriate soil salinity threshold in Northern Xinjiang area. The results confirmed that the soils in all treatments were desalinated after the whole growth period, and the decreasing rates varied within $18.89 \%-44.08 \%$ and $11.06 \%-30.83 \%$ for two plants, which showed linear and quadratic correlations with initial soil salinity, respectively $\left(R^{2}>0.92 * *, p<0.05\right)$. Meanwhile, higher soil salinity would inhibit crop growth and yield, and the initial soil salinity also represented the negative quadratic correlations with growth parameters $\left(R^{2}>0.92 * *, p<0.01\right)$. The inhibition effect was enhanced with larger initial soil salinity. After the comprehensive consideration of soil salinity variation, crop growth and yield, the initial soil salinity was recommended under $8.91 \mathrm{~g} / \mathrm{kg}$ and $5.54 \mathrm{~g} / \mathrm{kg}$ to plant spring wheat and sequential cropping silage corn in Northern Xinjiang using drip irrigation.
\end{abstract}

Keywords: soil salinity, drip irrigation, spring wheat sequential silage corn, quantitative correlations, critical controlling threshold

DOI: $10.25165 /$ j.ijabe.20181102.3621

Citation: Wang Z H, Zhou B, Pei L, Zhang J Z, He X L, Lin H. Controlling threshold in soil salinity when planting spring wheat and sequential cropping silage corn in Northern Xinjiang using drip irrigation. Int J Agric \& Biol Eng, 2018; 11(2): $108-114$.

\section{Introduction}

Soil salinization has become one of the worldwide challenges that restricting the agricultural development, especially in arid and semi-arid area ${ }^{[1-3]}$. And Xinjiang province in China is definitely one of the most typical and representative arid areas, due to its extremely hot and dry climate, as the annual evaporation is 10 times larger than the annual rainfall ${ }^{[3]}$. However, the human life and regional economy relied on the agriculture so deeply that the government promoted the large-scale reclamation in Xinjiang since 1950s. However, due to the insufficient awareness of soil salinization and appropriate water-fertilizer management, $30.85 \%$

Received date: 2017-07-05 Accepted date: 2017-12-23

Biographies: Lei Pei, Master, research interests: precise irrigation theory and technology. Email: 593456188@qq.com; Jinzhu Zhang, PhD, research interests: precise irrigation theory and technology. Email: xjshzzjz@sina.cn; Xinlin $\mathrm{He}, \mathrm{PhD}$, research interests: precise irrigation theory and technology. Email: hexinlin2002@163.com; Henry Li, PhD, research interests: ecosystem science and management. Email: henrylin@psu.edu.

*Corresponding author: Zhenhua Wang, PhD, research interests: precise irrigation theory and technology. No.221 North Road 4, College of Water \& Architectural Engineering, Shihezi University, Shihezi 832000, Xinjiang, China. Tel: +86-13201093132, Fax: +86-993-2058083, Email: wzh2002027@163.com; Bo Zhou, PhD, research interests: high-efficiency drip irrigation technology and application. No. 17 Qinghua East Road, College of Water Resources and Civil Engineering, China Agricultural University, Beijing 100083, China. Tel: +86-10-62737559, Fax: +86-10-62737559, Email: zhoubo1989@cau.edu.cn. of the arable land was salinized ${ }^{[3]}$. Therefore, it is critical to deal with the soil salinization issue in Xinjiang Region.

Since 1996, the drip irrigation technology was imported and successfully applied in planting cotton in Xinjiang. Afterwards, it was widely promoted and became the most practical irrigation method because of the desalting effect and relatively lower salt zone around crop roots, apart from other advantages ${ }^{[4,5]}$. Thus drip irrigation offers a better way to utilize the salty soil in agriculture at Xinjiang, and improves the economic returns ${ }^{[6,7]}$. In order to establish the appropriate application mode in this specific area, scholars studied the water-salt transportation characteristics $^{[8-12]}$, and the effects of soil salinity on photosynthesis $^{[13-19]}$, soil-resistance assessment, etc. ${ }^{[20-23]}$. However, these results were mainly obtained from the crops planted and harvested within a whole growing period in a specific area, and the crop type and area environment were limited to find out the soil salinity tolerance.

Besides, the Chinese government decided to change the simple agricultural structure in Xinjiang since 2008. Oversized cotton plantation was gradually transferred to food crops, and the majority of them was wheat, which became the most important food crop in Xinjiang $^{[24]}$. Then sequential cropping silage corn was applied to utilize the solar heat resource after spring wheat harvesting. It is a good way to increase food crop yield with limited water and heat resources. But if we want to promote this agricultural pattern to the larger scale in Xinjiang, how would soil salinity affect crop 
growth and yield? Would drip irrigation technology be helpful in this planting pattern and soil desalination, and what is the appropriate soil salinity controlling threshold? There is no relevant study conducted until now. Therefore, these issues need to be studied systematically, in order to provide a theoretical basis for the field management and efficient plantation of spring wheat and silage corn on the salty soils in Xinjiang.

\section{Materials and methods}

\subsection{Experiment environment}

The experiment was conducted in the Water-saving Irrigation Experimental Station at Shihezi city, Xinjiang $\left(85^{\circ} 59^{\prime} 47^{\prime \prime} \mathrm{E}\right.$, $\left.44^{\circ} 19^{\prime} 28^{\prime \prime} \mathrm{N}\right)$, from March to September 2015. The experimental site has the annual average sunshine duration of $2865 \mathrm{~h}$, the multi-year average precipitation of $207 \mathrm{~mm}$ and the annual mean evaporation of $1660 \mathrm{~mm}$, with the altitude of $412 \mathrm{~m}$ and the average surface slope of $6 \%$. In this area, the annual average wind speed is $1.5 \mathrm{~m} / \mathrm{s}$ and the frost-free period lasts for $170 \mathrm{~d}$, among which the accumulated temperatures are $3463.5^{\circ} \mathrm{C}$ and $2960.0^{\circ} \mathrm{C}$ for those days exceeding $10^{\circ} \mathrm{C}$ and $15^{\circ} \mathrm{C}$, respectively. The ground water here is below $5 \mathrm{~m}$. During the experiment period, the temperature and rainfall were daily recorded with the weather station (TRM-ZS2, manufactured in China), and the results are shown in Figure 1.

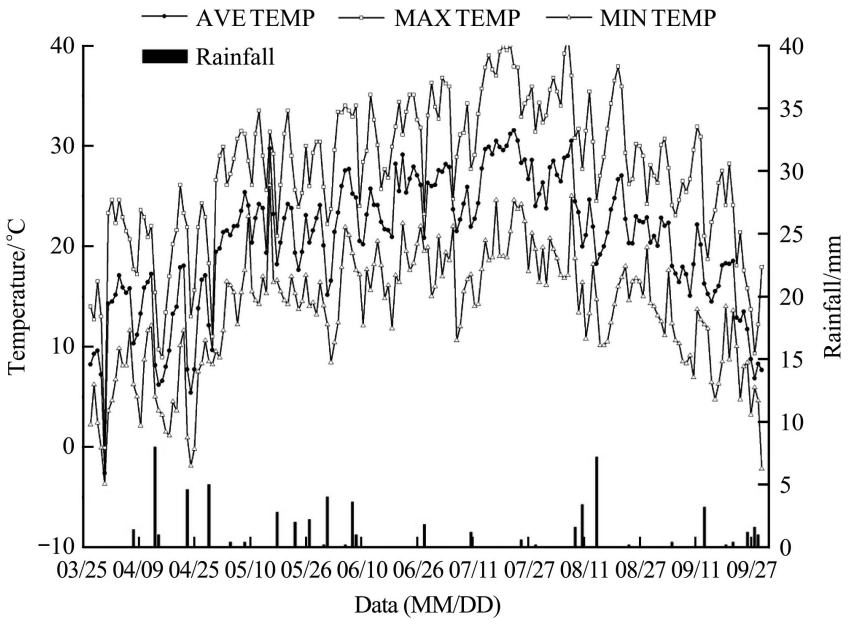

Figure 1 Variations of air temperature and rainfall during the experiment
The soil texture belongs to the medium $\operatorname{loam}^{[25]}$, with the average dry density of $1.53 \mathrm{~g} / \mathrm{cm}^{3}$ (within $120 \mathrm{~cm}$ depth), and the field capacity (FC) of $31.62 \%$.

\subsection{Experiment design}

The pot experiment was conducted in the study, and the inner diameter on top, at bottom and the pot height were $0.45 \mathrm{~m}, 0.35 \mathrm{~m}$ and $0.52 \mathrm{~m}$, respectively. There were three holes at the bottom of the pot with the diameter of $0.01 \mathrm{~m}$ each.

Based on the "Grading standards for the degree of salinity of cultivated soil" "[26], 5 treatments were set up in the experiment, including non-salinized soil (CK), light salinized soil (T1), moderate salinized soil (T2), severe salinized soil (T3) and salty soil (T4). Their salinities were $2.0 \mathrm{~g} / \mathrm{kg}, 5.0 \mathrm{~g} / \mathrm{kg}, 9.0 \mathrm{~g} / \mathrm{kg}$, $16.5 \mathrm{~g} / \mathrm{kg}$ and $24.5 \mathrm{~g} / \mathrm{kg}$, which equaled to $0.45 \mathrm{dS} / \mathrm{m}, 1.05 \mathrm{dS} / \mathrm{m}$, $1.85 \mathrm{dS} / \mathrm{m}, 3.35 \mathrm{dS} / \mathrm{m}$ and $4.95 \mathrm{dS} / \mathrm{m}$, respectively. In order to get the salty soils used in T1-T3 treatments, the non-salinized soil (CK) and salty soil (T4) were filtered, naturally dried, pulverized and then mixed with 3 specific volume ratios. Then the soils for 5 treatments were filled in the pots with a bulk density of $1.40 \mathrm{~g} / \mathrm{cm}^{3}$ till the height reached $45 \mathrm{~cm}$. There were 3 replications for each treatment and 15 pots in total. Medical plastic tubes were used to simulate drip irrigation emitters, and the outflow was controlled at $1.80 \pm 0.16 \mathrm{~L} / \mathrm{h}$.

Spring wheat "Xinchun 6" and silage corn "Ruiyu F98" were selected for the experiment. For the spring wheat, each pipe was applied to control 4 rows, and seeded on March $28^{\text {th }}$ at the depth of $4-5 \mathrm{~cm}$. They germinated on April $13^{\text {th }}$ and got the final singling of 40 plants in each pot during the trefoil stage. Harvesting came on June $29^{\text {th }}$ with the entire growth duration of $94 \mathrm{~d}$. During the period, the same water and fertilizer management was applied to 5 treatments. They were irrigated 11 times in total with an irrigation quota of $4400 \mathrm{~m}^{3} / \mathrm{hm}^{2}$. Meanwhile, $260.0 \mathrm{~kg} \mathrm{~N} / \mathrm{hm}^{2}$, $140.0 \mathrm{~kg} \mathrm{P}_{2} \mathrm{O}_{5} / \mathrm{hm}^{2}$ and $40.0 \mathrm{~kg} \mathrm{~K} 2 \mathrm{O} / \mathrm{hm}^{2}$ were applied, among which $65.0 \mathrm{~kg} \mathrm{~N} / \mathrm{hm}^{2}$ and $84.0 \mathrm{~kg} \mathrm{P}_{2} \mathrm{O}_{5} / \mathrm{hm}^{2}$ were used as the base fertilizer. As for the silage corn, 2 rows shared 1 pipe. They were seeded on July $5^{\text {th }}$ at the depth of 3-4 cm, and germinated on July $11^{\text {st }}$. 2 plants were the final singling for each pot, and they were harvested on September $30^{\text {th }}$, with the total growing duration of $87 \mathrm{~d}$. Same water and fertilizer control was continued, with the irrigation quota of $4000 \mathrm{~m}^{3} / \mathrm{hm}^{2}$, as well as $245 \mathrm{~kg} \mathrm{~N} / \mathrm{hm}^{2}, 125 \mathrm{~kg}$ $\mathrm{P}_{2} \mathrm{O}_{5} / \mathrm{hm}^{2}$ and $83.3 \mathrm{~kg} \mathrm{~K} \mathrm{O} / \mathrm{hm}^{2}$. Each pot was monitored independently to ensure the precise water and fertilizer management, and the detailed schedule is shown in Table 1.

Table 1 Water and fertilizer management during the experiment

\begin{tabular}{|c|c|c|c|c|c|c|c|c|}
\hline \multirow[b]{2}{*}{ Crops } & \multirow[b]{2}{*}{ Growing stages } & \multirow[b]{2}{*}{ Date (MM/DD) } & \multicolumn{2}{|c|}{ Water management } & \multicolumn{4}{|c|}{ Fertilizer management } \\
\hline & & & $\begin{array}{l}\text { Irrigation quota/ } \\
\mathrm{m}^{3} \cdot \mathrm{hm}^{-2}\end{array}$ & $\begin{array}{l}\text { Irrigation } \\
\text { times }\end{array}$ & $\begin{array}{c}\mathrm{N} / \\
\mathrm{kg} \cdot \mathrm{hm}^{-2}\end{array}$ & $\begin{array}{c}\mathrm{P}_{2} \mathrm{O}_{5} / \\
\mathrm{kg} \cdot \mathrm{hm}^{-2}\end{array}$ & $\begin{array}{c}\mathrm{K}_{2} \mathrm{O} / \\
\mathrm{kg} \cdot \mathrm{hm}^{-2}\end{array}$ & $\begin{array}{l}\text { Fertilization } \\
\text { times }\end{array}$ \\
\hline \multirow{6}{*}{ Spring wheat } & Seeding-Tillering & $03 / 28-04 / 27$ & 800 & 2 & - & - & - & - \\
\hline & Tillering-Jointing & $04 / 28-05 / 10$ & 400 & 1 & 18.2 & - & - & 1 \\
\hline & Jointing-Heading & $05 / 11-05 / 21$ & 1200 & 3 & 104.0 & 42.0 & 30.0 & 3 \\
\hline & Heading-Milkripe & $05 / 22-06 / 04$ & 1600 & 4 & 52.0 & 14.0 & 10.0 & 3 \\
\hline & Milkripe-Harvest & $06 / 05-06 / 29$ & 400 & 1 & 20.8 & & & 1 \\
\hline & Entire growth duration & $94 \mathrm{~d}$ & 4400 & 11 & 195.0 & 56.0 & 40.0 & 8 \\
\hline \multirow{4}{*}{ Silage corn } & Seeding-Jointing & $07 / 05-08 / 06$ & 1200 & 3 & - & - & - & - \\
\hline & Jointing-Tasseling & $08 / 07-08 / 30$ & 1200 & 3 & 105.0 & 53.6 & 35.7 & 3 \\
\hline & Tasseling-Pustulation & $08 / 31-09 / 16$ & 800 & 2 & 70.0 & 35.7 & 23.8 & 2 \\
\hline & Entire growth duration & $87 \mathrm{~d}$ & 4000 & 10 & 245 & 125 & 83.3 & 7 \\
\hline
\end{tabular}




\subsection{Critical parameters and calculation methods}

\subsubsection{Soil salinity variation}

$20 \mathrm{~g}$ soil was pre-treated and the supernatant liquid was obtained with the water-soil ratio of $5: 1^{[25]}$. The digital conductivity meter (DDS11-A, manufactured by Shanghai Leichi) was used to test its conductivity, and then Equation (1) was used to calculate the soil salinity:

$$
S=0.005 \times E C-0.25 \quad\left(R^{2}=0.992\right)
$$

where, $S$ means soil salinity, g/kg; $E C$ means conductivity, $\mu \mathrm{S} / \mathrm{cm}$.

Based on salt balance theory, the soil salinity variation rate was calculated with Equation (2):

$$
S_{\text {rate }}=\left(S_{b}-S_{a}\right) / S_{a} \times 100 \%
$$

where, $S_{\text {rate }}$ means the soil salinity variation rate, $\% ; S_{a}$ and $S_{b}$ mean the soil salinity at the beginning and end of each growing stage, \%; $\Delta S=S_{b}-S_{a}$, which means the soil salinity variation

\subsubsection{Growth indexes and yield}

After $15 \mathrm{~d}$ of the spring wheat germination and silage corn emerged, the plant heights and leaf areas were measured every $10 \mathrm{~d}$ till harvest. 3 plants in each pot were selected and their average value was calculated as the final results, and the leaf area of each plant was considered the sum of every single leaf area ${ }^{[27]}$.

After the harvest, the quantity of productive ear, seeds per ear, plant biomass and the thousand kernel weight (TKW) were tested for spring wheat yield evaluation ${ }^{[28]}$. For silage corn, the fresh weights of plant, leaf, stem and cluster were used as the yield indexes $^{[29]}$.

\subsection{Soil salinity threshold for spring wheat and sequential cropping silage corn}

Salt production function suggests the correlation between soil salinity and crop yield, and it is used to achieve rational utilization of salty soil in agriculture. Using the salt production function
(Equation (3) $)^{[30]}$, the results obtained by the experiment in this study were used to fit the correlations between soil salinity and crop yield. The TKW of spring wheat and plant fresh weight of silage corn were selected as the yield index, separately.

$$
Y_{r}=\frac{Y}{Y_{m}}=\left\{\begin{array}{cc}
1 & S=S_{t} \\
1-C\left(S-S_{t}\right) & S_{t}<S=S_{0} \\
0 & S>S_{0}
\end{array}\right.
$$

where, $Y_{r}, Y$ and $Y_{m}$ mean the relative yield, crop yield of the treatment and the maximum yield in $\mathrm{CK}$, respectively, g; $C$ means the descent coefficient of the crop yield; $S$ means the initial soil salinity, $\mathrm{g} / \mathrm{kg} ; S_{t}$ means the critical salt salinity without yield reduction, $\mathrm{g} / \mathrm{kg}$; and $S_{0}$ means the salt salinity without harvest, $\mathrm{g} / \mathrm{kg}$. Crop yield would not reduce when $S \leq S_{t}$. The crop yield was inhabited when $S_{t}<S \leq S_{0}$, and the negative impact was increased as $S$ raised. When $S>S_{0}$, crops could barely grow. $S_{10 \%}$ is defined as the initial soil salinity when crop yield decreased by $10 \%$, and it's used as the threshold of initial soil salinity.

Meanwhile, the quadratic correlations obtained in this paper were used to calculate $S_{10 \%}$. Thus it comes up with the appropriate threshold of soil salinity for spring wheat and sequential cropping silage corn, after the comprehensive consideration.

\section{Results and discussion}

\subsection{Soil desalting effect under different soil salinities}

Soil salinity variation within $0-40 \mathrm{~cm}$ soil during different growth stages of the spring wheat and silage corn are shown in Table 2. And the quantitative correlations between soil salinity variation as well as its variation rate and the initial soil salinity are

\begin{tabular}{|c|c|c|c|c|c|c|c|c|c|c|c|c|c|c|c|c|}
\hline \multirow{2}{*}{ Crop } & \multirow{2}{*}{ Treatment } & \multirow{2}{*}{$\begin{array}{c}\text { Initial } \\
\text { salinity/ } \\
\mathrm{g} \cdot \mathrm{kg}^{-1}\end{array}$} & \multicolumn{2}{|c|}{ Before seeding } & \multicolumn{2}{|c|}{ Seeding } & \multicolumn{2}{|c|}{ Tillering } & \multicolumn{2}{|c|}{ Jointing } & \multicolumn{2}{|c|}{ Heading } & \multicolumn{2}{|c|}{ Milk-ripe } & \multicolumn{2}{|c|}{$\begin{array}{l}\text { Whole growth } \\
\text { duration }\end{array}$} \\
\hline & & & $\begin{array}{c}\Delta S / \\
\mathrm{g} \cdot \mathrm{kg}^{-1}\end{array}$ & $\begin{array}{c}S_{\text {ratel }} \\
\%\end{array}$ & $\begin{array}{c}\Delta S / \\
\mathrm{g} \cdot \mathrm{kg}^{-1}\end{array}$ & $\begin{array}{c}S_{\text {ratel }} \\
\%\end{array}$ & $\begin{array}{c}\Delta S / \\
\mathrm{g} \cdot \mathrm{kg}^{-1}\end{array}$ & $\begin{array}{c}S_{\text {ratel }} \\
\%\end{array}$ & $\begin{array}{c}\Delta S / \\
\mathrm{g} \cdot \mathrm{kg}^{-1}\end{array}$ & $\begin{array}{c}S_{\text {ratel }} / \\
\%\end{array}$ & $\begin{array}{c}\Delta S / \\
\mathrm{g} \cdot \mathrm{kg}^{-1}\end{array}$ & $\begin{array}{c}S_{\text {rated }} \\
\%\end{array}$ & $\begin{array}{c}\Delta S / \\
\mathrm{g} \cdot \mathrm{kg}^{-1}\end{array}$ & $\begin{array}{c}S_{\text {rate }} / \\
\%\end{array}$ & $\begin{array}{c}\Delta S / \\
\mathrm{g}^{\cdot} \cdot \mathrm{kg}^{-1}\end{array}$ & $\begin{array}{c}S_{\text {ratel }} \\
\%\end{array}$ \\
\hline \multirow{5}{*}{$\begin{array}{l}\text { Spring } \\
\text { wheat }\end{array}$} & CK & 2.00 & -1.38 & -30.76 & 1.59 & 4.87 & 1.77 & 1.51 & -0.72 & -58.76 & 1.66 & 127.79 & -1.62 & -2.66 & -0.38 & -18.89 \\
\hline & $\mathrm{T} 1$ & 5.00 & -3.94 & -21.20 & 4.29 & 8.92 & 4.46 & 3.89 & -3.28 & -26.62 & 4.23 & 29.03 & -3.90 & -7.79 & -1.10 & -22.15 \\
\hline & $\mathrm{T} 2$ & 9.00 & -7.60 & -15.47 & 8.19 & 7.72 & -7.48 & -8.62 & -5.27 & -29.37 & 6.13 & 16.15 & -5.45 & -10.97 & -3.55 & -39.23 \\
\hline & $\mathrm{T} 3$ & 16.50 & -14.29 & -13.50 & 15.00 & 5.03 & -13.23 & -11.91 & -10.89 & -17.81 & 11.15 & 2.46 & -9.66 & -13.47 & -6.84 & -41.68 \\
\hline & $\mathrm{T} 4$ & 24.50 & -21.35 & -12.85 & 22.32 & 4.56 & -17.60 & -21.13 & -14.50 & -17.63 & 16.82 & 6.00 & -13.70 & -18.56 & -10.8 & -44.08 \\
\hline \multirow{5}{*}{$\begin{array}{l}\text { Silage } \\
\text { corn }\end{array}$} & $\mathrm{CK}$ & 1.62 & 2.53 & 55.47 & -1.98 & -21.79 & -1.50 & -24.27 & 2.18 & 45.10 & 2.26 & 3.48 & - & - & -0.28 & -11.06 \\
\hline & $\mathrm{T} 1$ & 3.90 & 6.72 & 72.85 & -5.70 & -15.20 & -5.34 & -6.30 & 6.74 & 26.35 & -5.85 & -13.27 & - & - & -0.87 & -12.93 \\
\hline & $\mathrm{T} 2$ & 5.45 & 8.42 & 54.19 & -8.00 & -4.93 & -7.37 & -7.80 & 9.50 & 28.69 & -6.99 & -26.35 & - & - & -1.43 & -16.92 \\
\hline & T3 & 9.66 & 13.32 & 38.27 & -11.93 & -10.53 & -10.69 & -10.52 & 12.90 & 20.88 & -9.93 & -23.21 & - & - & -3.39 & -25.68 \\
\hline & $\mathrm{T} 4$ & 13.70 & 17.42 & 27.17 & -16.02 & -8.02 & -14.38 & -10.24 & 16.98 & 18.04 & -12.05 & -29.02 & - & - & -5.37 & -30.83 \\
\hline
\end{tabular}
shown in Figure 2.

Table 2 Soil variation of different growth stages of spring corn and silage corn

Note: $\Delta S$ means the soil salinity variation and $S_{\text {rate }}$ represents the variation rate.

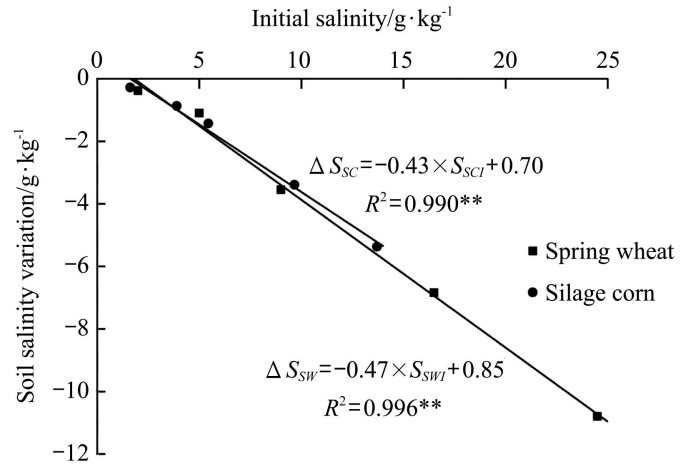

a. $\Delta S$ - initial salinity

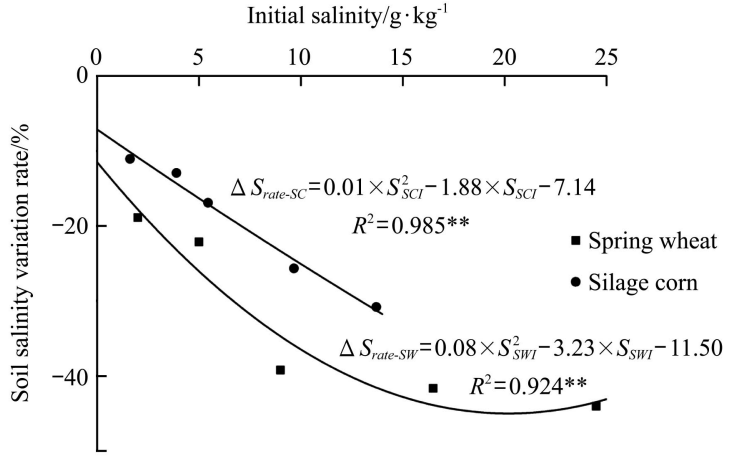

b. $S_{\text {rate }}$ - initial salinity

Note: $S_{S W I}$ and $S_{S C I}$ mean the initial soil salinity of spring wheat and silage corn, $\Delta S_{s w}$ and $\Delta S_{s c}$ mean their soil salinity variations, and $S_{r a t e-S W}$ and $S_{\text {rate-SC }}$ represent their variation rates. $* *$ in the figure means significant under $p<0.05$

Figure 2 Quantitative correlations between the initial soil salinity and its variation 
Although soil salinity showed different variation characteristics during different growth stages, all 5 treatments showed desalination effect through the whole growing duration, due to the leaching effect of irrigation. The overall desalination ratio for CK was $18.89 \%$, and larger initial soil salinity obviously enhanced the desalination ratio, so the maximum value was obtained in T4 treatment as $44.08 \%$. For different growth stages, the soil salinity dropped dramatically by $12.85 \%-58.76 \%$ before seeding and during jointing stage, while those in the seeding and heading stages increased on the contrary. This was mainly because the plant took the majority of the water itself to support their growth during this period and resulted in the salt accumulation $^{[31]}$.

Similar desalination trend was observed when planting silage corn afterwards. During the whole growth duration, soil salinity decreased by $11.06 \%-30.83 \%$ for 5 treatments. And larger initial soil salinity also showed strong desalination effect. However, different variation trends were observed between spring wheat and silage corn. For silage corn, soil salinity increased both before seeding and during tasseling stage. This was mainly due to the comprehensive dynamic balance of irrigation, fertilizer input,

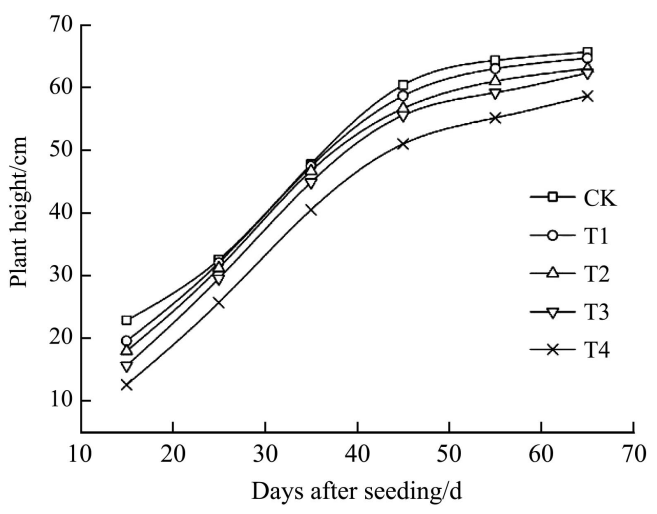

a. Spring wheat

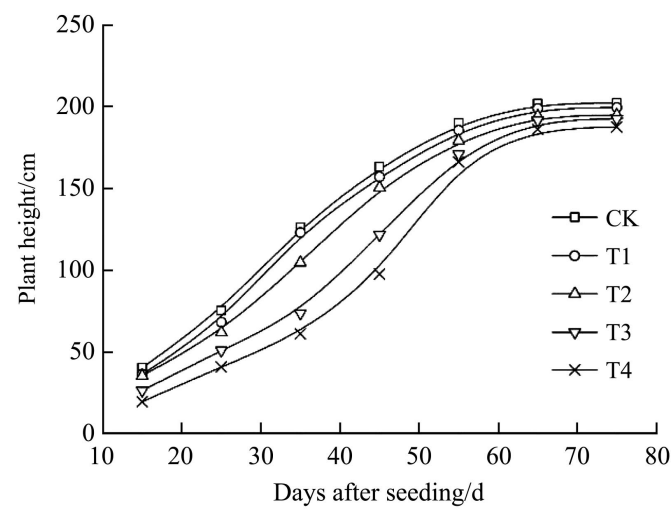

b. Silage corn

Figure 3 Effects of soil salinity on crop growth

According to the results from Figure 3, the heights of the spring wheat of 5 treatments showed S-shaped pattern with the quantity of days after seeding. During the seeding stage $(15 \mathrm{~d})$ and the tillering stage $(25 \mathrm{~d})$, the plant height increased slowly, and increases quickly afterwards till the heading period (45 d). After milkripe stage $(55 \mathrm{~d})$, the plant heights of all treatments tended to be stable with slightly increment. Indeed, soil salinity had an obvious impact on plant height during the growing duration. Compared to CK, the plant heights of T1-T4 treatments decreased by $0.71 \%-14.33 \%, 2.22 \%-21.36 \%, 5.09 \%-31.54 \%$, and $10.66 \%$ $44.91 \%$, respectively. Evaluating based on the whole growing

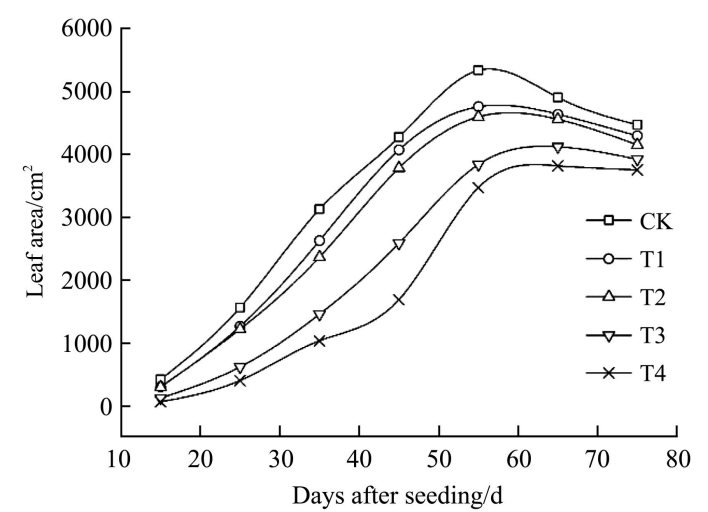

climate changes and soil evaporation, etc. ${ }^{[32]}$. As average temperature during its growing duration was relatively higher, plants needed relatively more water to support their growth. Consequently, the overall desalination effect of silage corn was weaker than that of the spring wheat.

Their quantitative correlations were acquired and showed in Figure 2. Soil salinity variation of the whole growth duration had negative linear correlation with its initial value for both two plants $\left(R^{2}>0.99 * *, p<0.05\right)$. Furthermore, their variation rate showed quadratic patterns with the initial soil salinities $\left(R^{2}>0.92 * *\right.$, $p<0.05)$. The variation velocity decreased with larger initial soil salinity for both spring wheat and silage corn. That meant the desalination effect was restricted by higher soil salinity. This was not only because the soil surface evaporation transferred to plant transpiration as more plants covered, but also due to the absorption of soil salinity by the plant itself $f^{[23,31]}$. Overall, the soil was desalinated after planting the spring wheat and sequential cropping silage corn using drip irrigation in Northern Xinjiang area.

\subsection{Effects of soil salinity on crop growth}

Effects of soil salinity on plant height and leaf area of crops are shown in Figure 3.

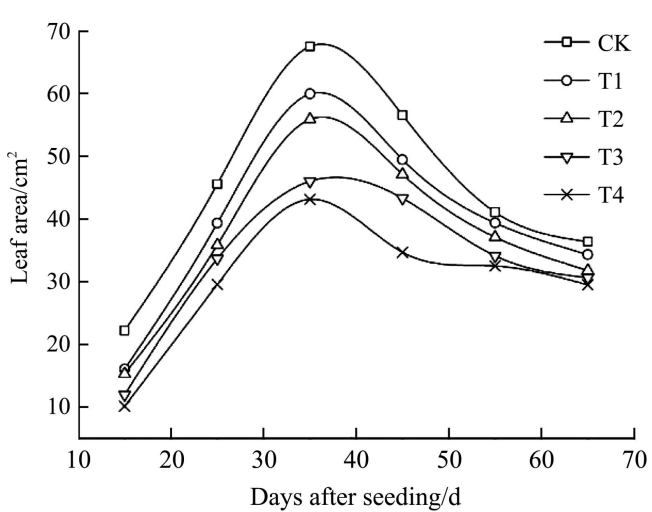

duration, T1 failed to show significant difference with CK, while those of T2-T4 reached the significant level $(p<0.05)$. On the other hand, the variation of leaf areas showed unimodal characteristics, as they increased at first and decreased afterwards. The spring wheat belonged to the vegetative growth phase from seeding stage $(15 \mathrm{~d})$ to jointing stage $(35 \mathrm{~d})$, and their leaf area increased continuously. Then the spring wheat entered the reproductive growth phase, and their leaves withered and became yellow, so the leaf area decreased. Similarly, largest leaf area was obtained with the lowest soil salinity in CK. During the whole growing duration, the difference between CK and T1-T4 was 
within 5.61\%-54.35\%.

Meanwhile, the silage corn showed similar variation trend with spring wheat, as its plant height and leaf area showed S-shaped pattern and unimodal characteristics with the growing days after seeding, separately. The results were similar to the previous studies $^{[27,31]}$. The higher soil salinity also showed negative impact on plant growth. However, different treatments showed the most significant differences during the period of 35-55 d after seeding for spring wheat, while that of spring wheat was 25-45 d after seeding. Besides, the maximum leaf area of spring wheat occurred at $35 \mathrm{~d}\left(43.12-67.51 \mathrm{~cm}^{2}\right)$, but silage corn delayed to $55 \mathrm{~d}$ (3473.23-5337.15 $\left.\mathrm{cm}^{2}\right)$. Based on these results, relatively low soil salinity (T1) was reasonable but higher soil salinity (T2-T4) would prohibit crop growth.

\subsection{Quantitative correlations between soil salinity and yield} indexes

Effects of soil salinity on yield indexes are shown in Table 3, and their quantitative correlations are shown in Figures 4 and 5.

As Table 3 indicated, the quantities of productive ear, seeds per ear, plant biomass and TKW of spring wheat were 84.67-118.33, 19.13-29.47, 1.02-2.19 g and 18.84-43.61 g for 5 treatments, respectively. Indeed, soil salinity had significant impacts on spring wheat yield indexes, as the yield indexes decreased with increased soil salinity. For the quantity of productive ear, plant biomass and TKW, there were no significant differences among CK, T1 and T2, while they were significant different from those of $\mathrm{T} 3$ and $\mathrm{T} 4$. However, no significant

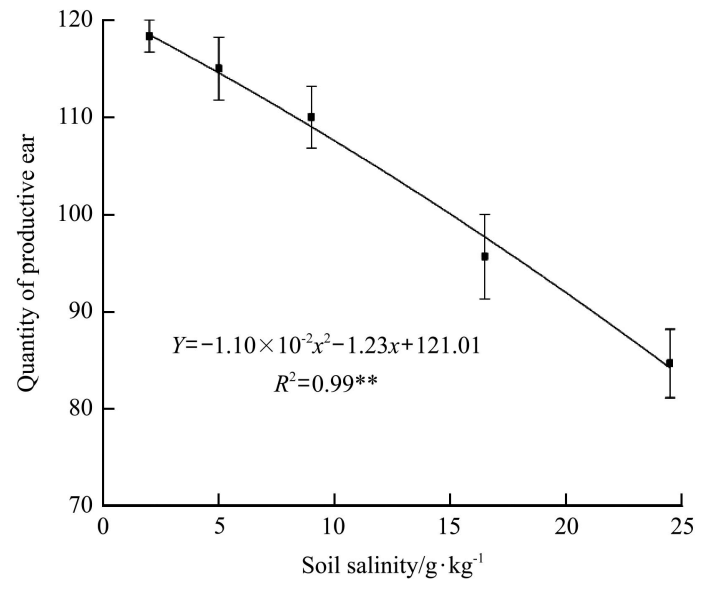

a. Quantity of productive ear

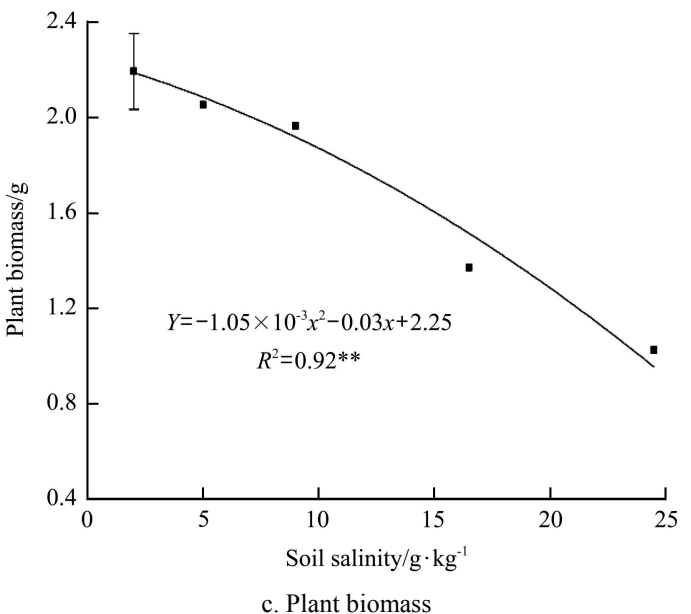

Note: $* *$ in the figure means significant under $p<0.05$. difference was obtained in seeds per ear between the adjacent treatments, nor significant difference between T3 and T4 in plant biomass. Furthermore, soil salinity showed quadratic and negative correlations with yield indexes (Figure $4, R^{2}>0.92 * *$, $p<0.01$ ), which indicated that soil salinity would restrain the spring wheat yield, and the inhibiting effect was more intense as soil salinity increased.

Table 3 Effects of soil salinity on yield of spring wheat and silage corn

\begin{tabular}{|c|c|c|c|c|c|}
\hline Crop & Treatment & $\begin{array}{l}\text { Quantity of } \\
\text { productive ear }\end{array}$ & Seeds per ear & $\begin{array}{c}\text { Plant } \\
\text { biomass/g }\end{array}$ & TKW/g \\
\hline \multirow{5}{*}{$\begin{array}{l}\text { Spring } \\
\text { wheat }\end{array}$} & CK & 118.3 & $29.47 \pm 1.07 \mathrm{a}$ & $2.19 \pm 0.16 \mathrm{a}$ & $43.61 \pm 0.14 \mathrm{a}$ \\
\hline & $\mathrm{T} 1$ & $115.00 \pm 3.21 \mathrm{a}$ & $28.53 \pm 1.99 \mathrm{a}$ & $2.09 \pm 0.11 \mathrm{a}$ & $42.38 \pm 0.19 \mathrm{a}$ \\
\hline & $\mathrm{T} 2$ & $110.00 \pm 3.21 \mathrm{a}$ & $26.40 \pm 0.12 \mathrm{ab}$ & $1.96 \pm 0.10 \mathrm{a}$ & $40.43 \pm 0.09 b$ \\
\hline & $\mathrm{T} 3$ & $95.67 \pm 4.33 b$ & $22.60 \pm 1.14 b c$ & $1.37 \pm 0.22 b$ & $31.83 \pm 0.62 \mathrm{c}$ \\
\hline & $\mathrm{T} 4$ & $84.67 \pm 3.53 c$ & $19.13 \pm 1.14 \mathrm{c}$ & $1.02 \pm 0.29 b$ & $18.84 \pm 0.96 \mathrm{~d}$ \\
\hline Crop & Treatment & $\begin{array}{l}\text { Plant fresh } \\
\text { weight } / g\end{array}$ & $\begin{array}{c}\text { Leaf fresh } \\
\text { weight/g }\end{array}$ & $\begin{array}{l}\text { Stem fresh } \\
\text { weight/g }\end{array}$ & $\begin{array}{c}\text { Cluster fresh } \\
\text { weight/g }\end{array}$ \\
\hline \multirow{5}{*}{$\begin{array}{l}\text { Silage } \\
\text { corn }\end{array}$} & CK & $850.20 \pm 18.45 \mathrm{a}$ & $83.19 \pm 5.23 \mathrm{a}$ & $351.88 \pm 28.10 \mathrm{a}$ & $415.13 \pm 14.40 \mathrm{a}$ \\
\hline & $\mathrm{T} 1$ & $804.60 \pm 7.88 \mathrm{ab}$ & $82.33 \pm 1.38 \mathrm{a}$ & $310.44 \pm 9.18 \mathrm{a}$ & $391.84 \pm 16.24 \mathrm{a}$ \\
\hline & $\mathrm{T} 2$ & $782.95 \pm 15.66 \mathrm{~b}$ & $81.66 \pm 0.93 a$ & $302.72 \pm 14.75 \mathrm{ab}$ & $399.57 \pm 3.07 \mathrm{a}$ \\
\hline & $\mathrm{T} 3$ & $635.65 \pm 24.81 \mathrm{c}$ & $69.97 \pm 0.45 b$ & $253.25 \pm 20.87 b c$ & $316.43 \pm 5.61 b$ \\
\hline & $\mathrm{T} 4$ & $496.89 \pm 6.25 \mathrm{~d}$ & $54.96 \pm 1.04 \mathrm{c}$ & $198.27 \pm 1.30 \mathrm{c}$ & $243.66 \pm 5.03 \mathrm{c}$ \\
\hline
\end{tabular}

Note: The letters in the table indicate the results of ANOVA. Same letter marked means "not significant" while different letters marked mean "significant" $(p<0.05)$.

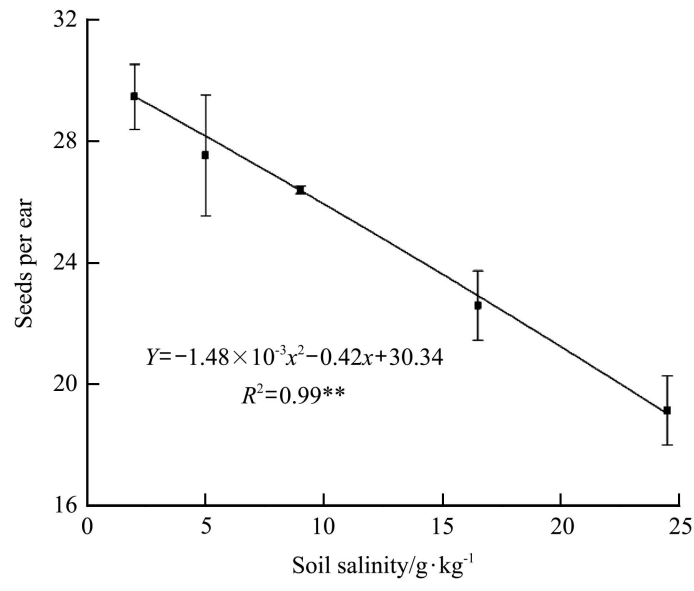

b. Seeds per ear

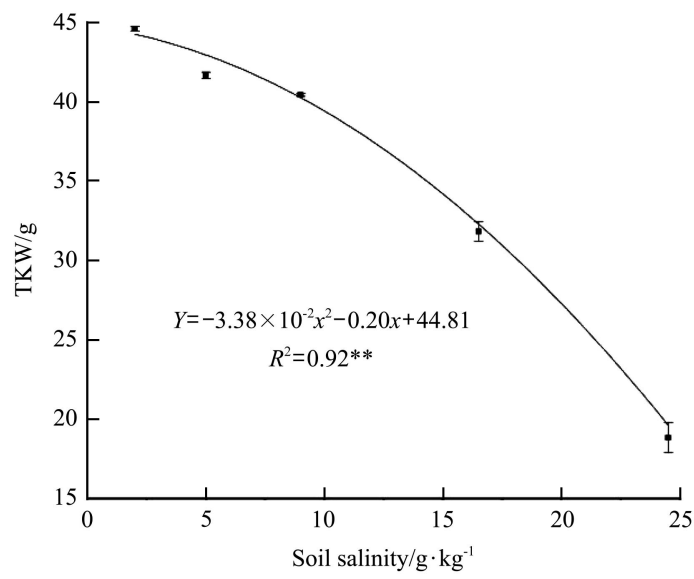

d. TKW

Figure 4 Quantitative correlations between soil salinity and spring wheat yield 

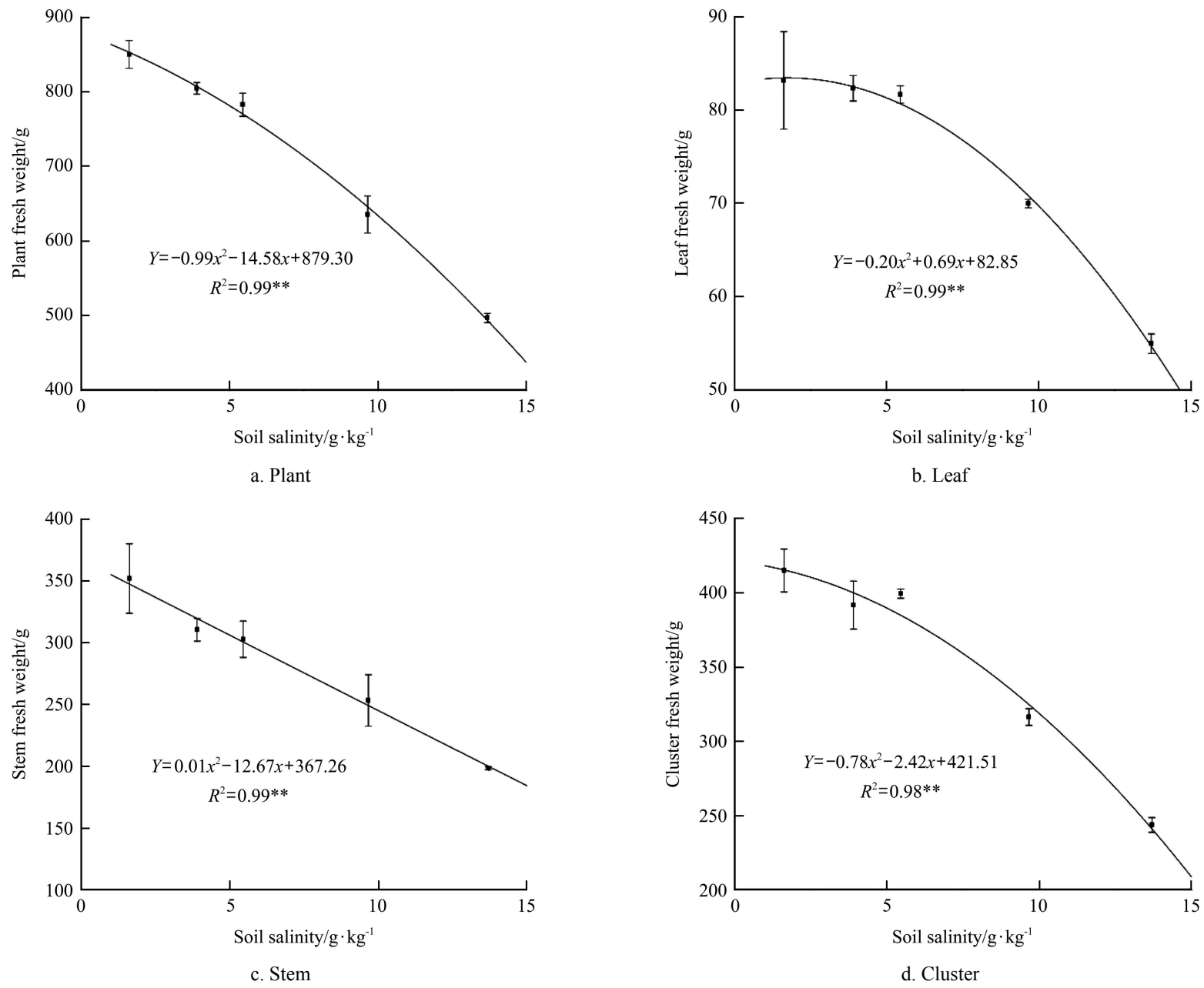

Note: $* *$ in the figure means significant under $p<0.05$

Figure 5 Quantitative correlations between soil salinity and silage corn yield

On the other hand, the fresh weights of plant, leaf, stem and cluster of silage corn were tested after harvesting. These yield indexes varied in 496.89-850.20 g, 54.96-83.19 g, 198.27-351.88 g and $243.66-415.13 \mathrm{~g}$ for different treatments. Obviously, the maximum value and minimum value were obtained in lowest and highest soil salinity treatment, separately. And the yield indexes also showed quadratic and negative correlations with soil salinity (Figure $5, R^{2}>0.96^{* *}, p<0.01$ ). Lower soil salinity showed relatively smaller impact on silage corn growth, but higher soil salinity showed its restriction dramatically. Hence, it's possible to evaluate the effects of soil salinity on crop yield according to their quantitative correlations to determine the appropriate soil salinity range.

\subsection{Critical soil salinity for spring wheat and silage corn}

The critical soil salinities of the spring wheat and silage corn using both salt production function and quadratic equation obtained in this paper are shown in Table 4.

When using salt production function, the salt salinity without yield reduction $\left(S_{t}\right)$ was $5.34 \mathrm{~g} / \mathrm{kg}$ for spring wheat and $2.92 \mathrm{~g} / \mathrm{kg}$ for silage corn. So the spring wheat in Northern Xinjiang could grow in non-salinized soil (CK) and light salinized soil (T1), but silage corn could merely maintain the yield in CK. When initial soil salinity exceeded $S_{t}$, their yield would decrease. Taking $S_{10 \%}$ as the threshold of salt tolerance, a $10 \%$ yield reduction could be expected when $S_{10 \%}$ were $8.91 \mathrm{~g} / \mathrm{kg}$ and $5.54 \mathrm{~g} / \mathrm{kg}$ for two crops. This also showed the results of planting the spring wheat in the moderate salinized soil (T2) and that for silage corn in T1. Afterwards, larger soil salinity would restrain crop yield seriously. The limited salt salinity $\left(S_{0}\right)$ were $40.94 \mathrm{~g} / \mathrm{kg}$ and $19.16 \mathrm{~g} / \mathrm{kg}$ for the spring wheat and silage corn separately; and under this condition, they would barely alive or without harvest.

Based on the quadratic equation acquired in this study, similar results were acquired within an acceptable range. The threshold of salt tolerance $\left(S_{10 \%}\right)$ of spring wheat and silage corn were $10.18 \mathrm{~g} / \mathrm{kg}$ and $5.66 \mathrm{~g} / \mathrm{kg}$. Therefore, it is concluded that planting spring wheat and silage corn with soil salinity less than $8.91 \mathrm{~g} / \mathrm{kg}$ and $5.54 \mathrm{~g} / \mathrm{kg}$ was acceptable in Northern Xinjiang using drip irrigation.

Table 4 Controlling threshold in soil salinity for spring wheat and silage corn

\begin{tabular}{|c|c|c|c|c|c|}
\hline \multirow{2}{*}{ Crop } & \multicolumn{3}{|c|}{ Critical soil salinity $/ \mathrm{g} \cdot \mathrm{kg}^{-1}$} & \multirow{2}{*}{ Function } & \multirow{2}{*}{$R^{2}$} \\
\hline & $S_{t}$ & $S_{0}$ & $S_{10 \%}$ & & \\
\hline \multirow{2}{*}{$\begin{array}{l}\text { Spring } \\
\text { wheat }\end{array}$} & 5.34 & 40.94 & 8.91 & $Y_{r}=-0.028 \times S+1.150$ & $0.97 * *$ \\
\hline & - & 39.36 & 10.18 & $Y=-0.034 \times S^{2}-0.20 \times S+44.81$ & $0.92 * *$ \\
\hline \multirow{2}{*}{$\begin{array}{c}\text { Silage } \\
\text { corn }\end{array}$} & 2.92 & 29.16 & 5.54 & $Y_{r}=-0.038 \times S+1.111$ & $0.99 * *$ \\
\hline & - & 23.33 & 5.66 & $Y=-0.990 \times S^{2}-14.58 \times S+879.30$ & $0.99 * *$ \\
\hline
\end{tabular}

\section{Conclusions}

The effects of soil salinity on its variation characteristics, crop growth, and yield of spring wheat and silage corn were studied in 
Northern Xinjiang using drip irrigation. By utilizing the quantitative correlations, it offered practical guidelines for local agriculture. Finally the following conclusions were obtained:

(1) The soil was desalinated after planting spring wheat and sequential cropping silage corn. During the whole growth duration, the overall desalination varied within $18.89 \%-44.08 \%$ and $11.06 \%-30.83 \%$ for two plants, and their variation values showed the negative linear correlation with the initial soil salinity $\left(R^{2}>0.99^{* *}, p<0.05\right)$.

(2) Within the soil salinity range of $25 \mathrm{~g} / \mathrm{kg}$, their variation rate showed quadratic pattern with the initial $\left(R^{2}>0.92 * *, p<0.05\right)$. The variation velocity decreased with larger initial soil salinity for both spring wheat and silage corn.

(3) The yield indexes showed negative parabolic correlations with initial soil salinity $\left(R^{2}>0.92^{* *}, p<0.01\right)$, which indicated the fact that higher soil salinity would prohibit plant growth and yield, and the inhibiting effect was more intense as soil salinity increased.

(4) It is recommended to plant spring wheat and sequential cropping silage corn in soil with salinity less than $8.91 \mathrm{~g} / \mathrm{kg}$ and $5.54 \mathrm{~g} / \mathrm{kg}$, respectively, in Northern Xinjiang using drip irrigation.

\section{Acknowledgements}

We are grateful for the financial support from the Natural Science Foundation of China (51169022), the National Key Technology Research and Development Program of the Ministry of Science and Technology of China (2015BAD20B03) and the High-level Scientific Research of Shihezi University (RCZX201433).

\section{[References $]$}

[1] Mokded R, Siwar F, Jihene J, Mohamed H H, Hans-Werner K, Annamaria R, Chedly A, Abderrazak S. Phytodesalination of a salt-affected soil with the halophyte Sesuvium portulacastrum $L$. to arrange in advance the requirements for the successful growth of a glycophytic crop. Bioresource Technology, 2010; 101(17): 6822-6828.

[2] Huang Q H, Long S J, Mao H T, Wang Z C. Design and experiment of protective blanket for soil salination control. Transactions of the CSAE, 2015; 31(17): 121-127. (in Chinese)

[3] Wang F F, Wu S X, Qiao M, Li H P, Yang H, Li Y L. Investigation and analysis on the salinization degree of cultivated land in Xinjiang based on 3S technology. Arid Zone Research, 2009; 26(3): 366-371. (in Chinese)

[4] Wang Z H, Yang P L, Zheng X R, He X L, Zhang J Z, Li W H. Soil salt dynamics in cotton fields with mulched drip irrigation under the existing irrigation system in Xinjiang. Transactions of the CSAM, 2014; 45(8): 149-159. (in Chinese)

[5] Zhou H P, Wang S L, Yao X H, Li B. Research on distribution characteristics and salt-discharging effect of directional migration of water and salt in soil through drip irrigation under plastic film. Journal of Hydraulic Engineering, 2013; 44(11): 1380-1388. (in Chinese)

[6] Wang S L, Zhou H P, Zhai X Y, Guan X Y. Study on directional salt transport and surface salt draining under mulched drip irrigation in arid areas. Journal of Hydraulic Engineering, 2013; 44(5): 549-555. (in Chinese)

[7] Shan L, Kang S Z, Wu P T. Chinese water-saving Agriculture. Beijing: China Agricultural Press, 2004.

[8] Yang J, Sun Z J, Luo C K, Ma F, Han L, Wang X. Effect of salt-water regulation on improving takyric solonetz land and yield of oil sunflower. Transactions of the CSAE, 2015; 31(18): 121-128. (in Chinese)

[9] Anapalli S S, Ahuja L R, Gowda P H, Ma L W, Marek G, Evett S R, Howell T A. Simulation of crop evapotranspiration and crop coefficients with data in weighing lysimeters. Agricultural Water Management, 2016; 177: 274-283.

[10] Sehmitz G H, Sehutze N, Petersohn U. News strategy for optimizing water application under trickle irrigation. Journal of irrigation and Drainage Engineering-ASCE, 2002; 128(5): 287-289.

[11] Wang Z H, Yang P L, Zheng X R, He X L, Zhang J Z, Li W H. Soil salinity changes of root zone and arable in cotton field with drip irrigation under mulch for different years. Transactions of the CSAE, 2014; 30(4): 90-99. (in Chinese)

[12] Skaggs T H, Genuchten M T, Shouse P J, Poss J A. Macroscopic approaches to root water uptake as a function of water and salinity stress. Agricultural Water Management, 2006; 86(1-2): 140-149.

[13] Sudhir P, Murthy S D S. Effects of salt stress on basic processes of photosynthesis. Photosynthetica, 2004; 42(4): 481-486.

[14] Chen T H H, Murata N. Glycinebetaine protects plants against abiotic stress: Mechanisms and biotechnological applications. Plant, Cell and Environment, 2011; 34(1): 1-20.

[15] Xu D Q. Some problems in stomatal limitation analysis of photosynthesis. Plant Physiology Communications, 1997; 33(4): 241-244.

[16] Steduto P, Albrizio R. Gas-exchange response to stomatal and non-stomatal limitations to carbon assimilation of sunflower under salinity. Environ-mental and Experimental Botany, 2000; 44(3): 243-255.

[17] Dunn G M, Neales T F. Are the effects of salinity on growth and leaf gas exchange related? Photosynthetica, 1994; 29: 33-42.

[18] Ou L J, Chen B, Zou X X. Effects of drought stress on photosynthesis and associated physiological characters of pepper. Acta Ecologica Sinica, 2012; 32(8): 2612-2619.

[19] Lowlor D W, Cornic G. Photosynthetic carbon assimilation and associated metabolism in relation to water deficits in higher plants. Plant, Cell and Environment, 2002; 25(2): 275-294.

[20] Mass E V, Hoffman G J. Crop salt tolerance-current assessment. Journal of the Irrigation and Drainage Division, 1977; 103(2): 115-134.

[21] Maas E V, Poss J A, Hoffman G J. Salinity sensitivity of sorghum at three growth stages. Irrigation Science, 1986; 7(1): 1-11.

[22] Gheysari M, Sadeghi S H, Loescher H W, Amiri S, Zareian M J, Majidi M M, Asgarinia P, Payero, J O. Comparison of deficit irrigation management strategies on root, plant growth and biomass productivity of silage maize. Agricultural Water Management, 2016; 182: 126-138.

[23] He X, Yang P L, Ren S M, Li Y K, Jiang G Y, Li L H. Quantitative response of oil sunflower yield to evapotranspiration and soil salinity with saline water irrigation. Int J Agric \& Biol Eng, 2016; 9(2): 63-73.

[24] $\mathrm{Wu} \mathrm{X} \mathrm{Y.} \mathrm{Industrialization} \mathrm{progress} \mathrm{of} \mathrm{high} \mathrm{quality} \mathrm{wheat} \mathrm{in} \mathrm{Xinjiang.}$ Xinjiang Agricultural Science, 2010; 47(2): 1-2.

[25] Bao S D. Soil agro-chemical analysis. Beijing: China Agricultural Press, 2010.

[26] Luo J X. Xinjiang reclamation saline improvement. Beijing: Water Conservancy and Electric Power Press, 1985.

[27] Mok H F, Dassanayake K B, Hepworth G, Hamilton, A J. Field comparison and crop production modeling of sweet corn and silage maize (Zea mays L.) with treated urban wastewater and freshwater. Irrigation Science, 2014; 32(5): 351-368.

[28] Maas E V, Poss J A. Salt sensitivity of wheat at various growth stages. Irrigation Science, 1989; 10(1): 29-40.

[29] Fouli Y, Duiker S W, Fritton D D, Hall M H, Watson J E, Johnson D H. Double cropping effects on forage yield and the field water balance. Agricultural Water Management, 2012; 115: 104-117.

[30] Tong W J. Study on salt tolerance of crop and cropping system optimization in Hetao irrigation district. Beijing: China Agricultural University, 2014.

[31] Chang T T, Shao X H, Ye H, Li W, Zhang J, Zhang Z Y. Irrigation scheduling for corn in a coastal saline soil. Int J Agric \& Biol Eng, 2016; 9(6): 91-99.

[32] He X L, Liu H G, Ye J W, Yang G, Li M S, Gong P, Aimaiti A. Comparative investigation on soil salinity leaching under subsurface drainage and ditch drainage in Xinjiang arid region. Int $\mathrm{J}$ Agric \& Biol Eng, 2016; 9(6): 109-118. 